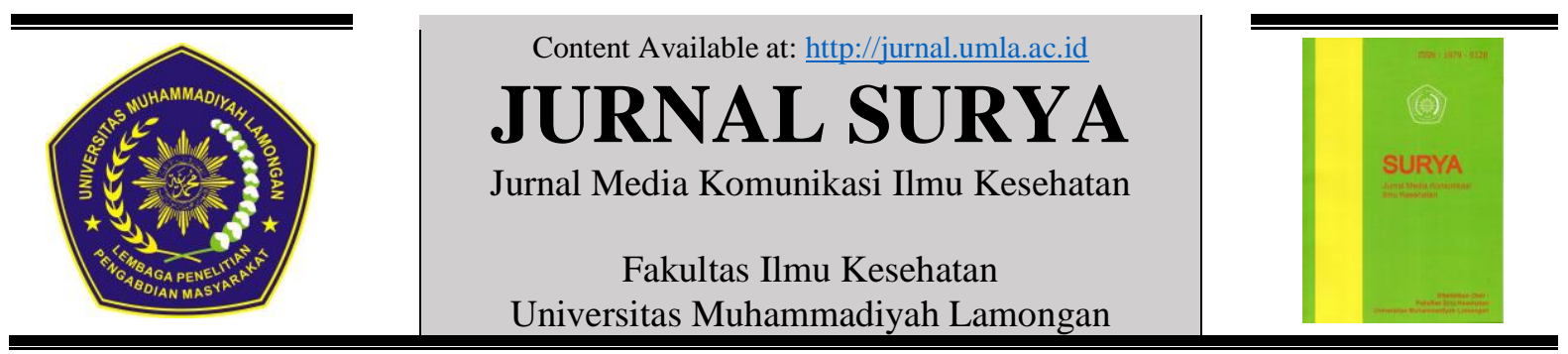

\title{
Hubungan Pengetahuan dan Sikap Orang Tua dengan Praktik Pencegahan Cedera pada Anak Pra Sekolah
}

\author{
Mokhtar Jamil ${ }^{1}$, Bayu Budi Laksono ${ }^{2}$ \\ ${ }^{1,2}$ Emergency Department, Poltekkes RS dr. Soepraoen Kesdam V, Malang, Indonesia
}

\section{ARTIKEL INFO}

\section{Article History:}

SM at 14-05-2020

$R$ V at $15-05-2020$

$P B$ at 25-06-2020

\section{Kata Kunci: \\ Pengetahuan \\ Sikap \\ Praktik \\ Pencegahan Cedera \\ Pra Sekolah}

Korespondensi Penulis:

jhe1301@gmail.com

bayubudi87@gmail.com

\begin{abstract}
ABSTRAK
Background: Karakteristik anak yang mengeksplorasi lingkungan menjadi penyebab utama terjadinya cedera pada anak. Pencegahan cedera sangat diperlukan karena cedera pada anak mempunyai dampak jangka panjang, pencegahan cedera menjadi kunci penting keberhasilan pengurangan cedera. Pengetahuan dan Sikap dari orang tua diduga menjadi faktor yang mendasari terjadinya cedera pada anak.
\end{abstract}

Objectives: Tujuan penelitian ini adalah mengetahui hubungan pengetahuan dan sikap oang tua dengan praktek pencegahan cedera.

Design: Jenis penelitian ini adalah korelasional dengan pendekatan cross sectional. Populasi adalah orang tua yang memiliki anak bersekolah di TK AL - Masithoh 04, jumlah sampel sebanyak 40 responden diambil dengan metode Total Sampling. Penelitian dilaksanakan 22 Maret 2018. Variabel pada penelitian ini adalah pengetahuan, sikap dan praktik pencegahan cedera. Uji statistik yang digunakan untuk variabel Pengetahuan adalah korelasi Sommers dan variabel Sikap menggunakan Lambda dengan taraf kepercayaan $95 \%$.

Results: Hasil penelitian variabel Pengetahuan terhadap Praktik dengan Sommers didapatkan nilai $\mathrm{p}=0,001$ dan $\mathrm{r}=0,447$; sedangkan variabel Sikap terhadap Praktik dengan Lambda didapatkan nilai $\mathrm{p}=0,000$ dan $\mathrm{r}=0,650$. Kedua variabel mempunyai hubungan yang signifikan serta kekuatan hubungan yang cukup dan kuat. Beberapa hal yang mempengaruhi hasil penelitian ini adalah paparan informasi sebelumnya, usia responden, tingkat pendidikan, serta jumlah anak.

Conclusions: Pencegahan cedera pada anak pra sekolah membutuhkan pengetahuan dan sikap orang tua yang baik untuk meningkatkan praktik orang tua dalam melakukan pencegahan cedera pada anak pra sekolah. Oleh karena itu, sangat penting bagi orang tua meningkatkan pengetahuan dan praktik pencegahan cedera pada anak pra sekolah. 
PENDAHULUAN

Cedera adalah dampak dari suatu agen eksternal yang menimbulkan kerusakan baik fisik maupun mental (Jamil, 2017). Cedera termasuk salah satu dari beberapa penyebab utama morbiditas dan mortalitas anak di dunia (Cocket, et al 2010). Cedera tersebut meliputi cedera lalu lintas, jatuh, terbakar, tenggelam, keracunan dan gigitan binatang (Atak, et al, 2010). Faktor lingkungan rumah tangga tempat tinggal anak yang tidak aman merupakan faktor yang paling berperan dalam kejadian cedera pada anak dan kemudian disusul oleh faktor pengawasan ibu yang masih rendah (Kuschithaswati, et al, 2007). Ibu yang praktik pencegahan cederanya kurang, frekuensi anak mengalami cedera lebih banyak atau sering (Widyaningsih, 2014).

Menurut World Health Organization (WHO) cedera mengakibatkan 5,8 juta kematian di seluruh dunia, dan lebih dari 3 juta kematian di antaranya terjadi dinegaranegara berkembang. WHO menyebutkan bahwa tidak kurang dari 875.000 anak dibawah 18 tahun di seluruh dunia meningggal pertahun karena cedera, baik cedera yang disengaja maupun cedera yang tidak disengaja (Atak,et al, 2010). Angka kejadian cedera tiap tahunnya mengalami peningkatan, dimana berdasarkan hasil survey oleh Riskesdas (Riset Kesehatan Dasar) prevalensi cedera tahun 2007 sebanyak 7,5 persen menjadi 8,2 persen pada tahun 2013 . Riskesdas tahun 2013 terjadi 5,4 \% cedera terjadi disekolah, dan $36,5 \%$ terjadi di rumah).

Hasil survey pendahuluan yang dilakukan pada bulan October 2017 di TK AlMasithoh 04 Dusun Jamuran Desa Sukodadi Kec. Wagir didapatkan dari 20 orang tua mengungkapkan anaknya pernah mengalami cedera. Hasil wawancara didapatkan cedera yang tersering yaitu jatuh berjumlah 13 anak, disusul 5 anak yang cedera luka bakar 1 anak pernah tersedak kelereng dan 1 anak pernah tenggelam.

Dari pengungkapan 20 orang tua melalui wawacara saat anak bermain di tangga, orang tua membiarkan dan tidak melarang anak, sering juga orang tua tidak memakaikan helm pada anak saat anak ikut serta berkendaran sepeda motor dengan berbagai alasan. Orang tua sering lalai untuk menyimpan korek api pengungkapan orang tua jika ada korek api anak akan memainkan korek api dengan membakar-bakar kertas dan menirukan pesulap yang pernah anak nonton di TV. Pernah terdapat kasus anak yang hampir tenggelam karena orang tua mengungkapkan tidak memakaikan pelampung pada anak dan tiba-tiba anak ikut masuk ke dalam kolam yang diperuntukkan untuk dewasa karena mengikuti kakaknya. Ada pengungkapan lain yaitu orang tua selalu mengunci pagar rumah saat anak dirumah karena rumah mereka berlokasi di pinggir jalan raya, ada pengungkapan lain lagi saat memandikan anak dengan air hangat ada salah satu orang tua mengungkapkan bahwa menuangkan air dingin terlebih dahulu ke bak mandi setelah itu baru air panas.

Sikap orang tua yang terlalu membiarkan anaknya akan berdampak pada keamanan dan keselamatan hidup anak (Dewi, 2016). Sikap adalah suatu bentuk evaluasi perasaan dan kecenderungan potensial untuk bereaksi yang merupakan hasil interaksi antara komponen kognitif, afektif dan konatif yang saling bereaksi didalam memahami, merasakan dan berprilaku terhadap suatu objek (Elmubarok, 2009). Banyak orang tua yang sering mengabaikan pengawasan terhadap anak sehingga mengakibatkan cedera (Kusbiantoro, 2014). Cedera adalah dampak dari suatu agen eksternal yang menimbulkan kerusakan, baik fisik maupun mental (Purwoko, 2006). Adapun factor yang mempengaruhi kejadian cedera adalah factor penjamu (host) yaitu orang tua dan anak factor penyebab cedera (agent), dan factor lingkungan (Muscary, Mary E.2010). Orang tua yang perilaku pencegahan cederanya kurang, frekuensi anak mengalami cedera lebih banyak atau sering (Widyaningsih, 2014). Cedera termasuk salah satu dari beberapa penyebab utama morbiditas dan mortalitas anak di dunia (Cocket,et $\mathrm{al} ; .2010)$.

Selain itu, Upaya pencegahan yang dapat dilakukan dalam kasus cedera di rumah tangga yaitu dengan memberikan informasi dan pengetahuan pada ibu serta meningkatkan pengetahuan dan keterampilannya demi kepentingan kesehatannya (Nursalam, 2008). Penting bagi orang tua, khususnya ibu untuk meningkatkan pengetahuan dalam mengetahui 
perubahan pertumbuhan dan perkembangan di setiap periode usia anak sehingga risiko cedera pada anak dapat dicegah. Jika orang tua memiliki pengetahuan yang baik maka tingkat pencegahan yang dilakukan juga cukup baik (Dewi, 2016).

Dari uraian tersebut maka peneliti tertarik untuk meneliti lebih jauh tentang "Hubungan Pengetahuan dan Sikap Orang Tua Dengan Praktik Pencegahan Cedera Pada Anak Pra Sekolah di TK Al-Masithoh 04 Dusun Jamuran Desa Sukodadi Kec. Wagir Kab. Malang"

\section{METODE}

Jenis penelitian ini adalah korelasional dengan pendekatan cross sectional. Populasi adalah orang tua yang memiliki anak bersekolah di TK AL Masithoh 04, jumlah sampel sebanyak 40 responden diambil dengan metode Total Sampling. Penelitian dilaksanakan 22 Maret 2018. Variabel yang diukur pada penelitian ini adalah pengetahuan dan praktik pencegahan cedera. Uji statistik yang digunakan untuk variabel Pengetahuan adalah korelasi Sommers dan variabel Sikap menggunakan Lambda dengan taraf kepercayaan 95\%. Intrumen penelitian menggunakan kuesioner untuk variabel Pengetahuan berjumlah 24 soal denga pilihan ganda, sedangkan untuk variabel Sikap berjumlah 14 soal dengan rentang pilihan jawaban dari Sangat Setuju (SS) sampai Sangat Tidak Setuju (STS). Praktek pencegahan cidera dievaluasi dengan metode recall menggunakan kuesioner sejumlah 14 soal dengan pilihan Ya Tidak.

\section{HASIL PENELITIAN}

TK AL - Masithoh 04 ini terletak di Desa Sukodadi Kecamatan Wagir Kabupaten Malang. Dalam menjalankan tugasnya dibidang pendidikan di TK Al- Masithoh 04 memiliki jumlah guru sebanyak 2 orang dengan murid berjumlah 40 terdiri dari 2 kelas. Sebelah utara berbatasan dengan persawahan, sebelah selatan dengan sebuah Masjid, sebelah barat dan timur berbatasan dengan rumah penduduk.
Data Umum Penelitian

\begin{tabular}{lcc}
\hline \multicolumn{1}{c}{ Data } & F & \% \\
\hline Umur Orang Tua & & \\
1. 17-25 Tahun & 15 & 37,5 \\
2. 26-35 Tahun & 18 & 45 \\
3. 46-55 Tahun & 7 & 17,5 \\
Total & $\mathbf{4 0}$ & $\mathbf{1 0 0}$ \\
\hline Pendidikan Orang Tua & & \\
1. SD & 14 & 35 \\
2. SMP & 11 & 27 \\
3. SMA & 15 & 38 \\
Total & $\mathbf{4 0}$ & $\mathbf{1 0 0}$ \\
\hline Pekerjaan Orang Tua & & \\
1. Swasta & 15 & 37 \\
2. Wiraswasta & 2 & 5 \\
3. Buruh & 6 & 15 \\
4. Tidak Bekerja/IRT & 17 & 43 \\
Total & 40 & $\mathbf{1 0 0}$ \\
\hline Umur Anak & & \\
1. 6 Tahun & 8 & 20 \\
2. 5 Tahun & 29 & 72,5 \\
3. 4 Tahun & 3 & 7,5 \\
Total & $\mathbf{4 0}$ & $\mathbf{1 0 0}$ \\
\hline Jenis Kelamin Anak & & \\
1. Laki-laki & 19 & 47,5 \\
2. Perempuan & 21 & 52,5 \\
Total & $\mathbf{4 0}$ & $\mathbf{1 0 0}$ \\
\hline A Ke Ke & & \\
\hline
\end{tabular}

Anak Ke

1. Anak Pertama $20 \quad 50$

2. Anak Kedua $16 \quad 40$

3. Anak Ketiga 2

4. Anak ke $>3 \quad 2 \quad 5$

Total $\quad 40 \quad 100$

Cedera Yang Pernah Dialami

Anak

1. Kendaraan Bermotor 1

2. Luka Bakar 2

3. Jatuh $33 \quad 82.5$

4. Keracunan 2

5. Tersedak 12 2,5

6. Cedera Rumah Tangga $\quad 1 \quad 2.5$

Total $\quad 40 \quad 100$

Sumber Informasi

1. Tidak Pernah $16 \quad 40$

2. Petugas Kesehatan $\quad 10 \quad 25$

3. Teman/Sesama Orang Tua $6 \quad 15$

4. Media massa 6015

5. Lainnya 205

Total $40 \quad \mathbf{4 0}$ Berdasarkan tabel diatas, hasil penelitian dapat diintepretasikan bahwa umur terbanyak pada orang tua anak pra sekolah di TK AL - Masithoh 04 Desa Sukodadi adalah hampir setengahnya berumur 26-35 Tahun 18 orang $(45 \%)$. Hampir setengah dari responden berpendidikan SMA yaitu 15 orang (38\%). 
Hampir setengah responden tidak bekerja atau sebagai ibu rumah tangga (IRT) sebanyak 17 orang $(43 \%)$ Sebagian besar anak di TK AL Masithoh 04 Desa Sukodadi berumur 5 tahun sebanyak 29 anak $(72,5 \%)$ dan sebagian besar berjenis kelamin perempuan sebanyak 21 anak $(52,5 \%)$. Setengah dari responden menyatakan anaknya merupakan anak pertama yaitu 20 orang $(50 \%)$ dan sebagian besar riwayat cedera yang dialami anak yaitu jatuh sebanyak 33 anak (82.5\%). Hampir setengahnya dari responden yaitu orang tua tidak pernah mendapatkan informasi tentang pencegahan cedera sebanyak 16 orang $(40 \%)$.

\section{Data Khusus Penelitian}

\begin{tabular}{lcc}
\hline \multicolumn{1}{c}{ Data } & F & \% \\
\hline $\begin{array}{l}\text { Pengetahuan Orang Tua } \\
\text { Tentang Pencegahan }\end{array}$ & \\
Cedera & & \\
1. Baik & 3 & 7 \\
2. Cukup & 24 & 60 \\
3. Kurang & 13 & 33 \\
Total & $\mathbf{4 0}$ & $\mathbf{1 0 0}$ \\
\hline Sikap Orang Tua Tentang & & \\
Pencegahan Cedera & & \\
1. Sikap Positif & & \\
2. Sikap Negatif & 16 & 40 \\
Total & 24 & 60 \\
& $\mathbf{4 0}$ & $\mathbf{1 0 0}$ \\
Praktik Pencegahan Cedera & & \\
1. Baik & & \\
2. Cukup & 13 & 32 \\
3. Kurang & 9 & 23 \\
Total & 18 & 45 \\
& $\mathbf{4 0}$ & $\mathbf{1 0 0}$ \\
\hline
\end{tabular}

Berdasarkan tabel diatas didapatkan bahwa pengetahuan responden sebagian besar termasuk dalam kategori cukup sebanyak $60 \%$ yaitu 24 orang. Sikap orang tua terhadap pencegahan cedera anak pra sekolah sebagian besar negative yaitu 24 orang $(60 \%)$ sedangkan sebagian besar dari responden melakukan praktik pencegahan cedera dalam kategori kurang yaitu 20 orang (50\%).

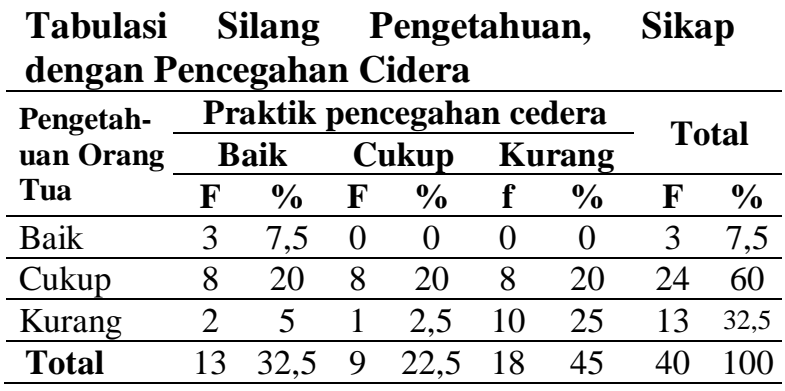

\begin{tabular}{|c|c|c|c|c|c|c|c|c|}
\hline \multicolumn{9}{|c|}{ Sommers D p $=0.001, R=0.447$} \\
\hline \multirow{2}{*}{$\begin{array}{l}\text { Sikap } \\
\text { Orang Tua }\end{array}$} & \multicolumn{2}{|c|}{ Baik } & \multicolumn{2}{|c|}{ Cukup } & \multicolumn{2}{|c|}{ Kurang } & \multicolumn{2}{|c|}{ Total } \\
\hline & $\mathbf{F}$ & $\%$ & $\mathbf{F}$ & $\%$ & $\mathbf{F}$ & $\%$ & $\mathbf{F}$ & $\%$ \\
\hline Positif & 14 & 35 & 1 & 2,5 & 1 & 2,5 & 16 & 40 \\
\hline Negatif & 0 & 0 & 5 & 12,5 & 19 & 47,5 & 24 & 60 \\
\hline Total & 14 & 35 & 6 & 15 & 20 & 50 & 40 & 10 \\
\hline \multicolumn{9}{|c|}{ Lambda $p=0.000, R=0.650$} \\
\hline
\end{tabular}

variabel Pengetahuan didapatkan nilai $p$ value $=0.001$ dan koefisien Gamma sebesar (+) 0,447 yang berarti terdapat terdapat hubungan pengetahuan ibu tentang pencegahan cedera dengan praktik pencegahan cedera pada anak pra sekolah dengan sifat kekuatan positif dengan kekuatan hubungan sedang. Nilai korelasi Somers D sebesar (+) 0,447 yang menunjukkan bahwa korelasi bersifat positif dan berkekuatan sedang. Bersifat positif berarti semakin tinggi pengetahuan yang dimiliki maka semakin tinggi pula praktik pencegahan cedera atau sebaliknya, semakin rendah pengetahuan yang dimiliki maka semakin rendah pula praktik pencegahan cedera.

Pada variabel Sikap didapatkan nilai $\mathrm{p}$ value $=0.000$ dan $R=0.650$ yang artinya terdapat hubungan antara sikap orang tua dengan praktik pencegahan cedera pada anak pra sekolah dengan hubungan bersifat positif dengan kekuatan hubungan kuat. Nilai korelasi Lamda (r) sebesar (+) 0,650 menurut Dahlan (2011), kekuatan korelasi (r) kuat jika terdapat pada rentang 0,60-0,799 sehingga hasil penelitian ini menunjukkan bahwa korelasi (r) bersifat positif dan berkekuatan kuat.

\section{PEMBAHASAN}

\section{Pengetahuan Orang Tua tentang Pencegahan Cedera pada Anak}

Berdasarkan dari hasil penelitian, sebanyak 24 responden $(60 \%)$ termasuk dalam pengetahuan ibu kategori cukup. Sisanya yaitu sebanyak 13 responden (33\%) termasuk dalam pengetahuan ibu kategori kurang dan 3 responden (7\%) termasuk dalam pengetahuan ibu kategori baik. Hal ini menunjukan bahwa sebagian besar responden berpengetahuan cukup dalam pencegahan cedera pada anak pra sekolah. Pengetahuan pada ibu juga dapat dipengaruhi oleh faktor pendidikan. Dari data karakteristik responden 
menunjukan sebagian besar 38\% (15 orang) ibu berpendidikan SMA.

Menurut Notoatmodjo (2007) konsep dasar pendidikan adalah suatu proses belajar yang berarti dalam pendidikan terjadi proses pertumbuhan, perkembangan atau perubahan kearah yang lebih dewasa, lebih baik dan lebih matang pada diri individu, kelompok atau masyarakat. Tingkat pendidikan yang tinggi cenderung mampu menerima dan memahami informasi yang masuk lebih baik, dan bahkan mampu mengaplikasikannya dengan baik (Wawan \& Dewi, 2010). Dalam penelitian Dewi (2016) di dapatkan hasil bahwa kejadian cedera anak terbanyak dialami oleh ibu dengan tingkat pendidikan rendah, semakin meningkatnya pendidikan ibu, maka ibu akan makin dapat mengidentifikasi resiko cedera pada anak.

Berdasarkan teori, hasil penelitian dan penelitian terkait dapat disimpulkan bahwa terdapat perbedaan pengetahuan ibu yang berpendidikan tinggi dengan ibu yang berpendidikan rendah, ibu yang memiliki pendidikan tinggi tingkat pengetahuan yang dimiliki lebih baik di banding dengan ibu yang berpendidikan rendah, sehingga pernyataan tersebut menunjukan bahwa faktor pendidikan sangat berpengaruh terhadap tingkat pengetahuan seseorang.

Selain pendidikan responden, Faktor lain yang mempengaruhi pengetahuan yaitu sumber informasi. Berdasarkan hasil penelitian dapat diinterpretasikan bahwa sumber informasi orang tua yang pernah mendapatkan informasi tentang pencegahan cedera siswa dan siswi di TK AL - Masithoh 04 Desa Sukodadi adalah hampir setengahnya tidak pernah mendapat informasi sebanyak 16 orang (40\%) dan sebagian kecil lainnya sumber informasi dari media massa (majalah, koran, dan tv) sebanyak 2 orang (5\%). Hal ini menunjukan bahwa sumber informasi mempengaruhi pengetahuan ibu karena sebagian besar pengetahuan berasal dari orang lain atau informasi dari media massa. Dari hasil penelitian ini, peneliti berasumsi bahwa dari faktor-faktor yang mempengaruhi pengetahuan tentang pencegahan cedera sesuai dengan fakta di lapangan yang di dapat peneliti yaitu riwayat pendidikan, dan sumber informasi.

\section{Sikap Orang Tua tentang Pencegahan Cedera pada Anak}

Berdasarkan hasil penelitian, sikap orang tua anak prasekolah di TK AL Masithoh 04 Dusun Jamuran didapatkan sebagian besar orang tua sebanyak 24 orang $(60 \%)$ tergolong sikap negative sedangkan hampir setengahnya dari orang tua anak prasekolah yang tergolong sikap positif sebanyak 16 orang (40\%). Hal ini menunjukkan bahwa sebagian besar responden memiliki sikap negative terhadap pencegahan cedera pada anak prasekolah. Menurut John H.Harvey dalam Ahmadi (2009) sikap adalah kesiapan merespon suatu hal secara konsisten dalam bentuk positif atau negative terhadap objek atau situasi. Pada penelitian Barik (2016) mengungkapakan sikap seseorang dapat dipengaruhi oleh beberapa faktor diantaranya pengalaman pribadi, tingkat pendidikan, pengaruh media massa, usia dan pekerjaan. Hal ini juga sesuai dalam teori Kliegman, dkk (2007) bahwa pendidikan, media massa dan pengalaman pribadi seseorang dapat mempengaruhi pembentukkan sikapnya. Teori tersebut menunjukkan banyak faktor yang dapat mempengaruhi pembentukkan sikap seseorang bahwa sikap satu orang dengan orang lain akan berbeda.

Dari hasil penelitian hampir setengah dari responden berumur 17-25 tahun sebanyak 15 orang (37.5\%). Pada usia 17-25 tahun merupakan periode pertama pengenalan dengan dunia orang dewasa, seseorang dalam periode ini akan mulai mencari tempat dunia kerja dan dunia hubungan social. Pada usia 17-25 tahun yaitu masa-masa transisi dimana seeorang belum dikatakan matang dalam berpikirnya. Sehingga kematangan umur seseorang akan berpengaruh dalam sikap orang tersebut. Hal ini sesuai dengan teori Nursalam (2008) bahwa semakin cukup usia seseorang, tingkat kemampuan dan kekuatan seseorang akan lebih matang dalam berpikir. Orang tua yang belum matang dalam segi umurnya seperti usia 17-25 tahun merupakan massa umur yang bisa dikatakan belum matang dalam berpikir maka banyak dari orang tua yang akan bersikap cenderung negative pada pencegahan cedera anak prasekolah.

Berdasarkan hasil penelitian bahwa tingkat pendidikan pada orang tua siswa dan 
siswi di TK AL - Masithoh 04 Desa Sukodadi adalah hampir setengahnya berpendidikan SD sebanyak 14 orang $(35 \%)$ dan ada juga berpendidikan SMP sebanyak 11 orang (27\%) .Pada penelitian Kusbiantoro tahun 2014 menyatakan pendidikan merupakan salah satu factor ekstrinsik yang mempengaruhi sikap, semakin tinggi pendidikan seseorang semakin berpengaruh terhadap pembentukkan sikap seseorang. Pengetahuan berperan dalam pembentukkan sikap seseorang, pengetahuan membuat seseorang berpikir akan suatu objek atau stimulus (Morrongiello, 2009). Dengan semakin tingginya pendidikan orang tua maka sikap dalam pencegahan cedera pada anak prasekolah semakin positif dikarenakan pendidikan sangat berperan dalam pembentukkan sikap dimana membuat seseorang berpikir terlebih dahulu sebelum bertindak.

\section{Praktek Pencegahan Cedera Orang Tua pada Anak}

Berdasarkan hasil penelitian pada tabel 4.2 praktik pencegahan cedera oleh orang tua prasekolah di siswa dan siswi di TK AL - Masithoh 04 Desa Sukodadi didapatkan hampir setengahnya melakukan praktik pencegahan kurang sebanyak 18 orang (45\%). Hal ini menunjukkan sebagian besar responden berpraktik kurang dalam pencegahan cedera pada anak. Menurut Notoatmodjo (2010) sikap dan pengetahuan dapat mempengaruhi praktik atau perilaku seseorang. Praktik pencegahan cedera pada anak prasekolah penting dilakukan oleh orang tua, karena dapat meminimalisir resiko anak megalami cedera. Beberapa alasan kenapa penyebab kurangnya praktik pencegahan cedera pada orang tua siswa-siswi di TK ALMasithoh 04 Dusun Jamuran di karenakan sumber informasi yang kurang.

Dari hasil penelitian hampir setengahnya orang tua siswa-siswi di TK AL - Masithoh 04 Desa Sukodadi tidak pernah memperoleh sumber informasi tentang pencegahan cedera sebanyak 16 orang (40\%). Hal ini menunjukkan hampir setengah dari responden tidak pernah memperoleh informasi tentang pencegahan cedera. Tingkat pengetahuan seseorang juga mempengaruhi praktik, yang mana semakin baik pengetahuan seseorang maka semakin baik praktik yang dilakukan. Hal ini mendukung teori dari
Notoatmodjo (2012) bahwa pengetahuan tidak hanya dipengaruhi oleh pendidikan tetapi ada faktor lainnya salah satunya sumber informasi. Kurangnya informasi pada orang tua anak tentang pencegahan cedera, maka praktik yang dilakukan orang tua juga akan berkurang.

Dari hasil penelitian pada diperoleh sebagian besar sikap orang tua siswa-siswi Tk $\mathrm{Al}$ - Masithoh 04 Desa Sukodadi sebanyak 24 orang $(60 \%)$ bersikap negative. Pada penelitian Barik tahun 2016 mengemukakan bahwa penting bagi orang tua untuk meningkatkan sikap dalam mengantisipasi cedera pada anak usia prasekolah karena merupakan salah satu upaya pencegahan mengurangi dan meminimalisir risiko cedera pada anak.. Sehingga sikap sangat mempengaruhi tindakan atau praktik seseorang karena sikap orang tua yang terlalu membiarkan anaknya maka resiko terjadinya cedera pada anak akan bertambah dengan begitu sikap orang tua siswa-siswi di TK AL - Masithoh 04 Desa Sukodadi yang cenderung negative maka memiliki praktik yang kurang pula.

\section{Hubungan Pengetahuan Orang Tua dengan Praktek tentang Pencegahan Cedera pada Anak}

Berdasarkan tabel hasil tabulasi silang antara pengetahuan dan praktik yang kemudian dimasukkan ke dalam SPSS 16 dengan uji statistik Somers $D$ didapatkan hasil bahwa nilai $\mathrm{p}=0,447$ yang berarti tergolong dalam kategori hubungan kuat dan nilai $\mathrm{r}=$ 0,001 , dimana nilai sig $(0,001<0,05)$ sehingga $\mathrm{H}_{0}$ ditolak yang artinya terdapat hubungan pengetahuan ibu tentang pencegahan cedera dengan praktik pencegahan cedera pada anak pra sekolah. Nilai korelasi Somers D sebesar (+) 0,447 yang menunjukkan bahwa korelasi bersifat positif dan berkekuatan sedang. Bersifat positif berarti semakin tinggi pengetahuan yang dimiliki maka semakin tinggi pula praktik pencegahan cedera atau sebaliknya, semakin rendah pengetahuan yang dimiliki maka semakin rendah pula praktik pencegahan cedera.

Berdasarkan hasil penelitian dapat diketahui bahwa responden yang termasuk dalam kategori pengetahuan kurang sebagian besar juga memiliki praktik yang kurang yaitu 
sebesar 25\% atau 10 orang dan sebagian kecil termasuk dalam kategori pengetahuan kurang dan memiliki praktik yang cukup 1 orang atau $2,5 \%$.

Adapun faktor - faktor yang mempengaruhi pengetahuan salah satunya yaitu sumber informasi. Berdasarkan hasil penelitian hampir setengahnya tidak pernah mendapatkan informasi sebanyak 16 orang (40\%) dan sebagian kecil lainnya sumber informasi dari media massa (majalah, koran, dan tv) sebanyak 2 orang (5\%). Berdasarkan hasil penelitian tersebut dapat diambil kesimpulan bahwa pengetahuan mempunyai hubungan yang signifikan terhadap praktik pencegahan cedera pada anak pra sekolah. Tingkat pengetahuan seseorang juga mempengaruhi praktik, yang mana semakin baik pengetahuan seseorang maka semakin baik praktik yang dilakukan. Pengetahuan adalah hasil penginderaan manusia atau hasil tau seseorang terhadap objek melalui indera yang dimilikinya seperti mata, hidung dan telinga (Notoadmodjo, 2011).

Hasil penelitian ini mendukung penelitian Atak, et.al (2010) yang menunjukkan bahwa ada hubungan antara pengetahuan dengan praktik pencegahan cedera pada anak. Kejadian cedera anak terbanyak dialami oleh ibu dengan tingkat pendidikan rendah. Berdasarkan analisa ditemukan bahwa semakin meningkatnya pendidikan ibu, maka ibu akan memiliki pengetahuan yang baik, sebagaimana telah disebutkan bahwa salah satu faktor yang mempengaruhi pengetahuan seseorang adalah dari tingkat pendidikannya.

Mengacu pada hasil penelitian tersebut dapat disimpulkan bahwa perlu adanya upaya untuk meningkatkan kualitas pengetahuan orang tua khususnya tentang bahaya cedera dan pencegahannya. Sumber pengetahuan dapat berasal dari informasi yang diterima oleh seseorang (Elmubarok, 2009). Bentuk pemberian informasi dapat berupa penyuluhan kesehatan tentang bahaya cedera dan pencegahannya. Pernyataan ini didukung oleh penelitian Amal (2013) yang menyatakan bahwa upaya pencegahan cedera, salah satunya adalah dengan meningkatan kualitas pengetahuan seseorang.

\section{Hubungan Sikap Orang Tua dengan Praktek tentang Pencegahan Cedera pada Anak}

Berdasarkan hasil analisa data untuk mengetahui hubungan antara sikap orang tua dan praktik pencegahan cedera pada anak yaitu dengan menggunakan uji korelasi Lamda. Berdasarkan tabel 4.3 diatas didapatkan $p$ value $=0,000(\mathrm{p}<0,05)$, sehinga $\mathrm{H}_{\mathrm{o}}$ ditolak dan $\mathrm{H} 1$ diterima sehingga kesimpulanya terdapat hubungan antara sikap orang tua dan praktik pencegahan cedera. Sikap orang tua tentang pencegahan cedera pada anak pra sekolah memiliki hubungan signifikan dengan praktik pencegahan cedera yang dilakukan orang tua.

Hasil ini juga sesuai dengan penelitian Barik et all (2016) yang menyatakan bahwa ada hubungan sikap dengan antisipasi cedera pada anak. Hasil penelitian ini juga mendukung penelitian dari Dewi (2016) yang menyimpulkan bahwa sikap memiliki hubungan dengan praktik. Praktik pencegahan cedera pada anak menjadi salah satu hal yang penting untuk meminimalkan kejadian cedera agar anak dapat tumbuh dengan sehat dan seseuai dengan pertumbuhan dan perkembanganya. Karena, sikap orang tua menjadi penentu dimana seorang orang tua harus tau sikap yang positif atau mendukung tentang pencegahan cedera maka kemudian dapat berperilaku atau melakukan praktik pencegahan cedera tersebut. Seperti kebiasaan orang tua mempraktikkan apa yang mereka katakan dengan menetapkan kebiasaan seperti mengenakan helm saat berkendara sepeda motor, ini berarti orang tua sudah mendukung yang berarti bersikap positif dan melakukannya dengan menetapkan kebiasaannya mengenakan helm untuk mencontohkan hal yang baik pada anak. Menurut Widyaningsih. A (2014) bahwa proses pelaksanaan praktik adalah didasari oleh pengetahuan yang kemudian diikuti oleh pembentukkan sikap. Banyak faktor yang dapat mempengaruhi sikap antara lain usia, pengalaman pribadi, media massa, pendidikan.

Berdasarkan hasil penelitian yang didapatkan di Tk Al - Masithoh 04 Dusun Jamuran bahwa orang tua yang anaknya merupakan anak pertama sebanyak 20 orang (50\%), yang merupakan anak kedua sebanyak 
16 orang $(40 \%)$, dan merupakan anak ketiga dan ke-4 dst masing-masing 2 orang (5\%). Jamil, (2017) mengatakan "bahwa tidak adanya pengalaman yang dimiliki oleh seseorang dengan suatu objek psikologis cenderung akan membentuk sikap negative terhadap objek tersebut". Teori lain yang juga mendukung yaitu Ridha (2014) yang mengungkapkan bahwa pengalaman pribadi haruslah meninggalkan kesan yang kuat, pengalaman yang dialami akan ikut membentuk dan mempengaruhi penghayatan, seseorang harus mempunyai pengalaman yang berkaitan dengan objek psikologi. Hal tersebut menunjukkan apabila seorang orang tua tidak memiliki pengalaman dalam bersikap pada anak tentang pencegahan cedera maka akan cenderung membentuk sikap yang negatife, sebaliknya apabila orang tua yang memiliki anak lebih dari satu maka akan memiliki pengalaman dalam membentuk sikap yang poisitif.

Praktik dengan sikap pencegahan cedera adalah hal sangat penting untuk dilakukan orang tua. Beberapa faktor-faktor yang dapat mempengaruhi praktik antara lain pendidikan, sumber informasi, dan sikap. Sikap merupakan salah satu faktor penting yang mempengaruhi praktik. Berdasarkan hasil penelitian yang didapatkan di Tk $\mathrm{Al}$ Masithoh 04 Dusun Jamuran bahwa sikap orang tua yang negative dan praktik pencegahan cedara yang kurang dengan presentase hasil sebanyak 19 orang $(47,5 \%)$ dan yang memiliki sikap positif dan praktik pencegahan cedera yang cukup dengan presentase hasil yaitu 1 orang $(2,5 \%)$. Seperti yang diungkapkan oleh Ahmadi (2009) dimana sikap akan menentukkan bagaimana orang tua akan bertindak untuk melindungi anaknya dari cedera dengan melakukan tindakan berupa pengawasan yang merupakan faktor yang berpengaaruh terhadap kejadian cedera. Teori tersebut juga sejalan dengan penelitian Kusbiantoro (2014) yang menyimpulkan bahwa yang paling dekat dengan praktik adalah sikap, karena sikap merupakan tindakan atau praktik yang belum terlaksana. Hal ini menujukkan dimana sikap orang tua yang negative maka akan mengarah kepada praktik yang kurang namun semakin positif sikapnya maka akan semakin baik dalam praktik yang dilakukanya.
Adapun faktor yang dapat mempengaruhi praktik orang tua dalam pencegahan cedera antara lain sumber informasi, sikap dan anak ke atau jumalah anak. Salah satu dari faktor praktik yang dapat dilihat dari hasil penelitian yaitu anak ke. Berdasarkan hasil penelitian hampir setengahnya dari orang tua anak di Tk $\mathrm{Al}-$ Masithoh 04 yang merupakan anak pertama sebanyak 20 orang (50\%), yang merupakan anak kedua sebanyak 16 orang (40\%), dan merupakan anak ketiga dan ke-4 dst masingmasing 2 orang (5\%).

Dalam teori menyebutkan bahwa setelah seseorang mendapatkan pengetahuan dari berbagai informasi atau pengalaman sendiri maupun pengalaman orang lain, maka seseorang tersebut akan mulai memikirkan stimulus untuk membentuk sikap sebelum melakukan tindakan (Notoatmodjo, 2010). Hal tersebut terbukti bahwa banyak dari orang tua belum punya banyak pengalaman dalam melakukan praktik pencegahan cedera pada anak karena merupakan pengalaman pertama memiliki anak berbeda dengan orang tua yang merupakan anak kedua, ketiga maupun ke-4 dst, banyak pengalaman yang dimiliki oleh orang tua untuk melakukan praktik pencegahan cedera dari belajar pada pengalaman anak sebelumnya.

\section{KESIMPULAN}

Terdapat hubungan antara Pengetahuan orang tua tentang Pencegahan Cedera dengan Praktik Pencegahan Cedera pada Anak Pra Sekolah dengan nilai $p=0,001$ yang berarti terdapat hubungan yang signifikan dan nilai $\mathrm{r}=0,447$ yang berarti kedua variabel berhubungan sedang.

Terdapat hubungan antara sikap orang tua dengan praktik pencegahan cedera pada anak pra sekolah dengan nilai $\mathrm{p}=0.000$ yang berarti terdapat hubungan yang signifikan dan nilai kolerasi (r) sebesar 0,650 yang berarti kekuatan hubungan dalam kategori kuat. 


\section{DAFTAR PUSTAKA}

Ahmadi, Abu .2009. Psikologi Umum. Jakarta. : Rineka Cipta.

Amal, Ahmad., Yani Istadi., Kurnia Wijayanti. 2013. Hubungan Antara Tingkat Pengetahuan Dengan Sikap Ibu Dalam Pencegahan Keracunan Pada Anak Usia 1-5 Tahun. Studi observasional di Kelurahan Karangrejo Semarang. Prosiding Konferensi PPNI Jawa Tengah (112115).

Atak, N.et.al. 2010. Usubutun, S.A. Household survey: Unintentiona Injury Frequency and Related Factors among Children under Five Years in Malaty. The Turkish Journal of Pediatrics. Vol. 52:285-293.

Barik, L. Ardila., Rohmah Nikmatur,. Hamid, ali Mohammad. 2016. "Hubungan sikap ibu dengan Antisipasi Cedera pada Anak Usia Pre School di Desa Karanganyar Ambulu. Universitas Muhammadiyah Jember".

Cockett, Andrea, \& Day, Helen. 2010. Children's High Dependency Jakarta: Wiley-Blackwell

Dewi \& Indrawati. 2016. Hubungan Antara Pengetahuan dan Sikap Orang Tua Tentang Bahaya cedera dan Cara Pencegahannya Dengan Praktik Pencegahan Cerdera pada Anak Usia Toddler. GASTER, Vol. 8, No. 2:750 - 764.

Elmubarok, Zaim. 2009. Membumikan Pendidikan Nilai. Bandung: Alfabeta

Jamil, Mokhtar. 2017. Penanganan Kedaruratan Sehari-Hari Pada Anak Usia Dini di Rumah. Purwokerto: IRDH

Kliegman, R. M., Behrman, R. E., Jenson,H.B., Stanton, B. 2007. Nelson textbook of pediatrics (18thed). Philadelphia. Saunders Elsevier.
Kuschithawati, S. 2007. Faktor Risiko Terjadinya Cedera Pada Anak Usia Sekolah Dasar. Journal of Community Medicine and Public Health. Vol. 23, No. 3.

Kusbiantoro. D. 2014. Praktik Pencegahan Cedera Pada Anak Usia Toddler Ditinjau Dari Pengetahuan Dan Sikap Orang Tua Tentang Bahaya Cedera. SURYA. Vol.02, No.XVIII.

Morrongiello, B. A., Walpole, B., \& McArhut, B. A. 2009. Brief report: young children's risk of unintentional injury: a comparison of mothers' and fathers' supervision beliefs and reported practices. http://eresources.perpusnas.go.id/libra ry.php?id=00009.

Muscary, Mary, E. 2010. Panduan Belajar: Keperawatan Pediatrik. Jakarta: EGC.

Notoatmodjo, S. $2007 . \quad$ Kesehatan Masyarakat, Ilmu dan Seni. Jakarta: Rineka Cipta.

Notoatmodjo, S. 2010. Metodologi Penelitian Kesehatan Edisi Revisi. Jakarta: Rineka Cipta.

Notoatmodjo, S. 2011. Kesehatan Masyarakat, Ilmu dan Seni. Jakarta: Rineka Cipta.

Notoatmodjo, S. (2012). Metodologi Penelitian Kesehatan. Jakarta: Rineka Cipta.

Nursalam. 2008. Asuhan Keperawatan Bayi dan Anak (Untuk Perawat dan Bidan). Jakarta: Salemba Medika

Purwoko, S. 2006. Pertolongan Pertama dan RJP Pada Anak Edisi 4. Jakarta: Arcan

Ridha. 2014. Buku Ajar Keperawatan Anak. Yogyakarta: Pustaka Pelajar. 
Wawan \& Dewi, M. 2010. Teori dan Pengukuran Pengetahuan, Sikap dan Perilaku Manusia. Yogyakarta: Nuha Medika.

Widyaningsih. A, 2014 Hubungan Perilaku Ibu Dalam Pencegahan Cedera Dengan Kejadian Cedera Balita Di Serangan Yogyakarta. STIKES Aisyiyah Yogyakarta. Skripsi. Naskah publikasi. 